\title{
The Relationship Between Entrepreneurship Levels of the Students of (Sports Sciences) and their Athlete Identities
}

\author{
Mustafa Baş ${ }^{*}$, Elif Aydin² \\ 'Department of Sport Sciences, Trabzon, Trabzon University \\ ${ }^{2}$ School of Physical Education and Sports, Gümüşhane University, \\ Gümüşhane, Turkey \\ Study Area:Trabzon, Turkey \\ Coordinates: $41^{\circ} \mathrm{oo}^{\prime} 18$ ? $\mathrm{N} ; 39^{\circ} 43^{\prime} 21$ ? E
}

Key words:

\section{Abstract}

The study was carried out on a total of 240 university students, 111 (46.3\%) female and 129 (53.8\%) male. The "Personal Information Form" prepared by the researcher and the "University Students Entrepreneurship Scale". In the research, the survey model, one of the quantitative research designs, was used. While the entrepreneurship and athlete identity levels of the students differ significantly in the "social identity" and "negative affectivity" subdimensions according to gender, no significant difference was found in other sub-dimensions. By this relationship between entrepreneurship and athlete identity levels of the students, it was found that there is a positive and significant relationship between entrepreneurship, and social identity and negative affectivity. Further, a positive relationship between entrepreneurship, and social identity and negative affectivity was evidenced. It was determined that the limited sports sub-dimension was not a significant predictor of the entrepreneurship score. A statistically significant difference was found between university students' entrepreneurship and athlete identity levels and their gender, department, class and licensed athlete scores.

himself/herself as an athlete in the eyes of others. "Limited by Sports" is the degree to which an individual's athlete identity covers other self-concepts and causes him/her to create a unique image as an athlete. Finally, "Negative Affectivity" is defined as the degree of anxiety of individuals about poor performance or not being able to fulfill their roles as an athlete (Brewer et al., 1993).

Athlete identity can serve as a social and schematic role. In other words, athlete identity can provide a framework for interpreting information and can be an inspiration for consistent behavior. Besides, athlete identity plays a partly social role in terms of other people's perceptions. It can be said that the education provided in different departments of universities plays an important role in influencing the entrepreneurship perspective of students. With the education they receive at different educational levels, students gain knowledge and skills in issues such as innovation, uncertainty tolerance, aim to be successful, risk-taking, and control focus. In the field of sports, there is a need for entrepreneurs who can combine emerging opportunities with their ideas and take action with the increasing competition in the developing world. Sport is seen as a social and economic concept that develops day by identity" focuses on the degree to which the athlete sees

*Corresponding Author: mustafaabat@hotmail.com 
day, and sport has an educational dimension that fulfills a social, historical, and recreational purpose besides its task of improving health. In this respect, entrepreneurship characteristics in sports are seen in different dimensions. Entrepreneurship education in sports should provide and encourage students to identify opportunities, support their sport-related initiatives or promote existing sports organizations to adopt the entrepreneurial talents and characteristics of students to sports, including existing or newly formed organizations, foundations, nongovernment organizations in society, the state sector and social sectors (Jana, 2015).

Physical education and sports activities can be shown as the most appropriate and important training tool for the training and development of the physical and mental structure of young people. Sports, especially, contribute to the development of young generations in a constructive, qualified, creative way, with a high sense of national unity and solidarity, and thus economic, social, and cultural development (Yetim, 2015). Today, entrepreneurship has become one of the most influential factors in economic development. Entrepreneurs have great responsibilities for the development of the country. It is because, thanks to entrepreneurship, new job opportunities are created and important contributions are made to the solution of the problems in the economy and unemployment. Also, new products and services are offered to the markets thanks to entrepreneurs with different, original, and strategic thinking (Akyüz, 2013). Education has an important impact on the success of institutions and organizations that add different dimensions to the economic, political, and cultural structure of countries, as well as in entrepreneurship. Individuals state that they will increase their knowledge and abilities to have an entrepreneurial identity that succeeds with the education they have acquired, and they will gain sensitivity to the issues they did not realize before (Altan, 2014).

It is noteworthy that entrepreneurship contributes to the quality of life in society and affects socio-economic development. The athlete identity, which plays a social role in terms of people's perceptions, has an important effect on the entrepreneurship level of university students, but there is a need for entrepreneurs who can develop opportunities in the field of sports, and also introducing sports organizations and supporting sports-related initiatives brings many innovations to sports business fields and activities, and there is a need for university students who will provide economic and social benefits. Therefore, revealing the athletic identity of the students who graduated from the sports sciences faculty will reduce the idea of working in the state sector and increase the expectation of working in a private sector or the idea of starting a business. It is thought that it is possible to improve the level of entrepreneurship with athletes who are qualified, developmental, researcher, innovative, and creative. The necessity of entrepreneurship knowledge, which provides many opportunities and facilities and is an important issue, brings great responsibilities to university students, and the skills to get the necessary efficiency from this process are important for the future of athletes. Therefore, this study aims to examine the relationships between the entrepreneurship levels of the students studying at the Faculty of Sports Sciences and their athlete identities, and to compare athlete identity sub-dimensions according to some demographic characteristics (gender, licensed athlete status, department, and class variable) and to determine whether there is a difference between them.

\section{Methodology:}

In the research, the relational survey method was used to determine the current situation. Survey models are research models that aim to describe a past or present situation as it exists. The event, individual, or object subject to research is tried to be defined in its conditions and as it is. No effort is made to change or influence them in any way. The important thing is to observe and determine the phenomenon to be known properly. Relational survey models among survey models are research models that aim to determine the existence and/or degree of change between two or more variables (Karasar, 2005). The sample of the study was carried out on a total of 240 university students, 111 (46.3\%) female and 129 (53.8\%) male, studying at Trabzon University's Faculty of Sport Sciences in the academic year 2019-2020.

The "Personal Information Form" prepared by the researcher, the "University Students Entrepreneurship Scale" by Yilmaz \& Sümbül (2009), and the "Athlete Identity Measurement Scale" adapted into Turkish by Öztürk \& Koca (2013) developed by Brewer \& Cornelius (2001) were used as data collection tools. In the research, the survey model, one of the quantitative research designs, was used. The scale developed by Yilmaz \& Sümbül (2009) is designed to determine the entrepreneurial characteristics of students. This study aims to develop university students' entrepreneurship scale. The literature on entrepreneurship was examined by the researchers and a scale of 43 items was prepared. Before conducting a pre-test of this scale, expert opinions were consulted and in line with their opinions, the sentences in the scale were revised and reduced to 36 items. The sentences converted into Likert type form are arranged in 5-interval scale form from "Very often" (5) to "Never" (1). Cronbach Alpha reliability analyses and factor analysis (validity analysis) were performed with the data obtained after the trial application. As a result of the factor analysis made with Principal Component Analysis, it was determined that all items were collected in one dimension. As a result of the reliability analysis, the Cronbach Alpha reliability coefficient of the scale was determined as o.90.

The Athletic Identity Measurement Scale, which 
consists of 7 items developed by Brewer \& Cornelius (2001), will be used in the study to determine the athlete's identity. The scale was adapted to Turkish by Öztürk \& Koca (2013). The scale consists of 3 sub-dimensions: Social Identity, Limited by Sports, and Negative Affectivity. Öztürk \& Koca determined the reliability coefficients of the scale as .69 for the Social Identity sub-dimension, .79 for the Limited by Sports sub-dimension, and .59 for the Negative Affectivity sub-dimension. In the scale, participants are asked to evaluate each item on a seven-point scale ( $1=$ I never agree, 7 = I totally agree).agree). The high score obtained from the scale indicates that the athlete's identity is strong. In this study, the reliability of the Athlete Identity Measurement scale was found high as Cronbach's Alpha $=0.892$. Scales collected by the researcher were checked and those that were filled in incorrectly were excluded from the study. For independent groups, t-Test and One Way Analysis of variance were used, level of significance was taken as 0.05. SPSS 25.0o program was used to analyze the research data.

\section{Results:}

The descriptive values of the study group regarding the variables of the research are given below.

It was found that the skewness and kurtosis coefficients of the students' scores from the "University Students Entrepreneurship Scale" and "Athlete Identity Measurement Scale" ranged between -1.5 and +1.5 , and it was observed that the data were distributed normally (Tabachnick \& Fidell, 2013).

Table-1: T-test results of students' entrepreneurship and athlete identity levels by gender

\begin{tabular}{lllllll}
\hline Sub-dimensions & Gender & $\mathrm{n}$ & ${ }^{-} \mathrm{X}$ & $\mathrm{Sd}$ & $\mathrm{t}$ & $\mathrm{p}$ \\
\hline Entrepreneurship & Female & 111 & 3.56 & 0.24 & 0.206 & 0.807 \\
& Male & 129 & 3.55 & 0.21 & & \\
Social identity & Female & 111 & 5.54 & 0.49 & -2.203 & $.022^{*}$ \\
& Male & 129 & 5.68 & 0.48 & & \\
Limited by Sports & Female & 111 & 5.37 & 0.66 & 1.909 & 0.057 \\
& Male & 129 & 5.15 & 1.03 & & \\
Negative & Female & 111 & 4.72 & 0.96 & -2.828 & $.005^{*}$ \\
affectivity & Male & 129 & 5.08 & 0.97 & & \\
\hline
\end{tabular}

Table-2: T-test results of students' entrepreneurship and athlete identity levels according to the status of being a licensed athlete

\begin{tabular}{lllllll}
\hline Sub-dimensions & \multicolumn{1}{l}{ Licensed } & $\mathrm{n}$ & $X$ & $\mathrm{Sd}$ & $\mathrm{t}$ & $\mathrm{P}$ \\
\hline Entrepreneurship & Yes & 117 & 3.53 & 0.19 & -1.947 & 0.057 \\
& No & 123 & 3.58 & 0.25 & & \\
Social identity & Yes & 117 & 5.64 & 0.56 & 0.834 & 0.405 \\
& No & 123 & 5.59 & 0.42 & & \\
Limited by Sports & Yes & 117 & 5.72 & 0.72 & 9.182 & 0 \\
& No & 123 & 4.81 & 0.8 & & \\
Negative affectivity & Yes & 117 & 4.58 & 1.02 & -5.364 & 0 \\
& No & 123 & 5.23 & 0.83 & &
\end{tabular}

A significant difference between the entrepreneurship and athlete identity levels of the students in the "social identity" and "negative effectivity" sub-dimensions, while no significant difference was found in the other sub- dimensions. In the sub-dimensions of Social identity and negative effectivity, the difference was found in favour of the male.

While in Table-2 there is a significant difference between the entrepreneurship and athlete identity levels of the students in the "limited by sports" and "negative effectivity" sub-dimensions according to the status of being a licensed athlete, while no significant difference was found in the other sub-dimensions. There was a difference in favour of yes in the limited by sports sub-dimension, and in favour of no in the negative effectivity sub-dimension.

Table-3: One-way ANOVA results of students' entrepreneurship and athlete identity levels by department

\begin{tabular}{|c|c|c|c|c|c|c|c|}
\hline Variables & Department & $\mathrm{n}$ & $X$ & $\mathrm{Sd}$ & $\mathrm{Sd}$ & F & $\mathrm{P}$ \\
\hline \multirow{4}{*}{$\begin{array}{l}\text { Entrepre- } \\
\text { neurship }\end{array}$} & Coaching & 88 & 3.63 & .24 & 2 & \multirow[t]{3}{*}{13.129} & \multirow[t]{3}{*}{$.000^{*}$} \\
\hline & Teaching & 75 & 3.56 & .21 & 237 & & \\
\hline & Sports Manag. & 77 & 3.46 & 0.17 & 239 & & \\
\hline & Tukey: Sports & Mar & & & achir & g/ Teach & ing \\
\hline \multirow{4}{*}{$\begin{array}{l}\text { Social } \\
\text { identity }\end{array}$} & Coaching & 88 & $5 \cdot 51$ & 0.37 & 2 & \multirow[t]{4}{*}{8.327} & \multirow[t]{3}{*}{$.000^{*}$} \\
\hline & Teaching & 75 & $5 \cdot 55$ & 0.46 & 237 & & \\
\hline & Sports Manag. & 77 & 5.8 & 0.59 & 239 & & \\
\hline & \multicolumn{6}{|c|}{ Tukey: Sports Management* Coaching/ Teaching } & \\
\hline \multirow{4}{*}{$\begin{array}{l}\text { Limited by } \\
\text { Sports }\end{array}$} & Coaching & 88 & $4 \cdot 52$ & 0.63 & 2 & \multirow[t]{3}{*}{122.309} & \multirow[t]{3}{*}{$.000^{*}$} \\
\hline & Teaching & 75 & $5 \cdot 3$ & 0.5 & 237 & & \\
\hline & Sports Manag. & & 4.62 & 1.08 & 239 & & \\
\hline & Tukey: Sports & Man & & & & o/ Тeack & ing \\
\hline \multirow{3}{*}{$\begin{array}{l}\text { Negative } \\
\text { affectivity }\end{array}$} & Coaching & 88 & $5 \cdot 42$ & .70 & 2 & \multirow[t]{3}{*}{20.831} & \multirow[t]{3}{*}{$.000^{*}$} \\
\hline & Teaching & 75 & 4.63 & .93 & 237 & & \\
\hline & Sports Manag. & & 4.62 & 1.08 & 239 & & \\
\hline
\end{tabular}

Table-4: One-way ANOVA results of students' entrepreneurship and athlete identity levels by class

\begin{tabular}{lllllllll}
\hline Variables & Class & $\mathrm{n}$ & $-\mathrm{X}$ & $\mathrm{Sd}$ & $\mathrm{Sd}$ & $\mathrm{F}$ & $\mathrm{P}$ & Tukey \\
\hline Entrepre & 1st grade & 55 & 3.65 & 0.23 & 3 & & & \\
neurship & 2nd grade & 53 & 3.7 & 0.09 & 236 & 23.71 & $.000^{*}$ & $1^{*} 3 / 4$ \\
& 3rd grade & 67 & 3.47 & 0.22 & 239 & & & \\
Social & 4thgrade & 65 & 3.45 & 0.19 & & & & \\
identity & 1st grade & 55 & 5.5 & 0.39 & 3 & & & \\
& 2nd grade & 53 & 5.79 & 0.36 & 236 & 16.164 & $.000^{*}$ & $1^{*} 2 / 4$ \\
& 3rdgrade & 67 & 5.36 & 0.4 & 239 & & & \\
Limited by & 4thgrade & 65 & 5.84 & 0.58 & & & & \\
Sports & ist grade & 55 & 4.51 & 0.58 & 3 & & & \\
& 2nd grade & 53 & 5.39 & 0.46 & 236 & 43.575 & $.000^{*}$ & $1^{*} 2 / 3 / 4$ \\
& 3rdgrade & 67 & 5.05 & 0.83 & 239 & & & \\
Negative & 4thgrade & 65 & 5.97 & 0.84 & & & & \\
affectivity & 1st grade & 55 & 5.28 & 0.83 & 3 & & & \\
& 2nd grade & 53 & 5 & 1.02 & 236 & 24.665 & .000 & $*$ \\
& 3rdgrade & 67 & 5.29 & 0.74 & 239 & & & \\
& 4thgrade & 65 & 4.15 & 0.87 & & & & \\
\hline
\end{tabular}

As per Table-3, a significant difference was found by the department between the entrepreneurship and athlete identity levels of the students in the "Entrepreneurship", "Social identity", "Limited by sports" and "Negative affectivity" sub-dimensions. According to the multiple comparison test (post-hoc) results, a significant difference was determined between Sports Management and Coaching and Teaching departments in favour of Coaching the entrepreneurship sub-dimension; between Sports 
Management and Coaching and Teaching departments in favour of Sports Management in the social identity subdimension; between Sports Management and Coaching and Teaching departments in favour Sports Management in the limited by sports sub-dimension; between Coaching and Sports Management and Teaching departments in favour of Coaching negative affectivity sub-dimension.

A significant difference was found by class between the entrepreneurship and athlete identity levels of the students in the "Entrepreneurship", "Social identity", "Limited by sports" and "Negative affectivity" sub-dimensions.

According to the multiple comparison test (post-hoc) results, a significant difference was determined in favour of 1st class between 1st class and 3rd class d 4th class in the entrepreneurship sub-dimension; in favour of $4^{\text {th }}$ class between 1st class and 2nd class 4 th class in the social identity sub-dimension; in favour of 4 th class between 1st class and 2nd class, 3 rd class $d$ th class in the limited by sports sub-dimension; in favour of 3 rd class between 4 th class and 1st class, 2nd class and 3rd classin the negative affectivity sub-dimension.

Table-5: Relationship between students' entrepreneurship and athlete identity levels

\begin{tabular}{llllc}
\hline Sub-dimensions & 1 & 2 & 3 & 4 \\
\hline Entrepreneurship & 1 & & & \\
Social identity & $.21^{* *}$ & 1 & & $\mathrm{p}<.01^{* *}$ \\
Limited by Sports & -.04 & $.62^{* *}$ & 1 & \\
Negative affectivity & $.27^{* *}$ & $-.21^{* *}$ & $-.53^{* *}$ & 1 \\
\hline
\end{tabular}

The entrepreneurship and athlete identity levels of students revealed a positive and significant relationship between entrepreneurship and social identity and negative affectivity (Table-5).

Table-6: Prediction level of entrepreneurship in students on their athlete identity

\begin{tabular}{|c|c|c|c|c|c|}
\hline Variables & \multicolumn{2}{|c|}{ StandardError } & $?$ & $\mathrm{t}$ & $\mathrm{p}$ \\
\hline Entrepreneurship & 2.515 & .199 & & 13.283 & .000 \\
\hline Social identity $\quad .149$ & .036 & .325 & 4.167 & .000 & \\
\hline Limited by Sports & -.023 & .023 & -.090 & -1.006 & .316 \\
\hline Negative affectivity & .067 & .017 & .293 & 4.085 & .000 \\
\hline $\mathrm{R}=.390 \mathrm{a}$ & $\mathrm{R}_{2}=.152$ & & 14.081 & & \\
\hline
\end{tabular}

The equation for the prediction level of entrepreneurship on athlete identity was significant in students. Sub-dimensions of social identity, limited by sports and negative affectivity explain $15.2 \%$ of entrepreneurship. As a result of the regression analysis, a positive relationship was found between entrepreneurship and social identity and negative affectivity. It is understood that the limited by sports sub-dimension is not a significant predictor of entrepreneurship score.

\section{Discussion and Conclusion:}

In this study, the relationships between the entrepreneurship and athlete identity of the students studying at the Faculty of Sports Sciences and gender, being a licensed athlete, department and class variables were examined and the results were discussed.

While there is a significant difference between the entrepreneurship and sports identity levels of the students in the "social identity" and "negative affectivity" subdimensions by gender, no significant difference was found in the other sub-dimensions. There was a difference in favor of males in social identity and negative affectivity subdimensions. According to Brewer, athlete identity is the manifestation of the role of the sports displayed together with individual identity (Brewer et al., 1993a). Athlete identity finds existence in important social dimensions such as experiences affecting self-perception (self), social interaction with other people, and engaging in sports activities (Proios, 2013). Therefore, it can be said that male students use sports roles more effectively than female students and they are more engaged in social interaction and sports activities. When the relevant literature is examined, different findings can be found in many studies in terms of athlete identity and gender variables. While some studies point out significant findings between athlete identity and gender in favor of male athletes (Weichman \& Williams, 1997), some studies do not support our research findings (Murphy et al., 1996). In the study at Miami University, Elasky (2006) found that the gender variable does not cause a significant difference in terms of athlete identity among university athletes-students. It was observed that there was no significant difference in terms of gender variable in the study group in which the athlete identity scale was applied. In other words, it was determined that male and female factors do not play an important role in determining athlete identity (Çetinkaya,2015). Görgülü et al., (2018) also found in their study that there are significant differences between male and female individuals in terms of gender variables and that male university students tend to evaluate their own athletic identities more in the eyes of others than female university students in the "social identity", "limited by sports", "negative affective" when the sub-dimensions of the athlete identity scale are examined.

While there is a significant difference between the entrepreneurship and athlete identity levels of the students in the "limited by sports" and "negative affectivity" subdimensions according to the status of being a licensed athlete, no significant difference was found in the other sub-dimensions. There was a difference in favor of yes in the limited by sports sub-dimension and in favor of no in the negative affectivity sub-dimension. In the study, Oregon (2010) could not find any significant difference between the duration of sports during school years and athlete identity. Adler \& Adler (1991), on the other hand, state that with the advancement of school years and sports experience, the sportive identity will become stronger. In the study conducted by Çetinkaya (2015), it was determined that the 


\section{ORIGINAL ARTICLE}

relationship between the license period of the participants and the athlete identity was not significant and that the license period was not a significant predictor of the athlete identity levels of the participants.

A significant difference was found between the entrepreneurship and athlete identity levels of the students in the sub-dimensions of "entrepreneurship", "social identity", "limited by sports" and "negative affectivity" according to the department. A significant difference was found between the entrepreneurship and athlete identity levels of the students in the sub-dimensions of "entrepreneurship", "social identity" "limited by sports" and "negative affectivity" according to the class. As per the relationship between entrepreneurship and athlete identity levels of the students, it was found that there is a positive and significant relationship between entrepreneurship and social identity and negativeaffectivity.

As a result of the regression analysis, it was found that there is a positive relationship between entrepreneurship and social identity and negative affectivity. It was determined that the sports restriction sub-dimension was not a significant predictor of the entrepreneurship score. As a result of the regression analysis, it was found that there is a positive relationship between entrepreneurship and social identity and negative affectivity. It was determined that the limited by sports sub-dimension was not a significant predictor of the entrepreneurship score.

A statistically significant difference was found between university students' entrepreneurship and athlete identity levels and their scores of gender, department, class, and status of being a licensed athlete. It was found that there is a positive relationship between entrepreneurship and social identity and negative affectivity. Accordingly, it can be said that the communication between the students and their social environments support their social identities. Some sports activities that the athlete's identity brings to the life of the individual can make a positive contribution to experiencing some psychological processes. Therefore, empirical, qualitative, or observational studies should be conducted to determine the relationship between students' athletic identity and entrepreneurial characteristics. Cultural and sports activities should be increased in order to keep people away from negative behaviors, and participation in these activities should be made more interesting. Especially, the fact that the sports students studying in the relevant departments of the physical education and sports field of universities are candidates to train future generations in the field of sports is thought that it will contribute to highlighting and protecting the sports identity and entrepreneurial characteristics.

\section{References:}

Adler, P.A. \& Adler, P. (1991): Backboards and Blackboards. Pub. by: New York: Columbia University.
Ambient Science, 2020: Vol. 07(Sp1); 283-287 DOI:10.21276/ambi.2020.07.sp1.oa40

Akyüz, Y. (2013): Üniversite ögrencilerinin KOSGEB desteklerine bakis açilari ve girisimcilik egilimleri üzerine bir arastirma (Usak Üniversitesi örnegi). Usak Üniversitesi Sosyal Bilimler Dergisi, 6(3):80-98.

Altan, M.Z. (2014): Türkiye'nin egitim çikmazi. Girisimci ögretim, girisimci ögretmen. Pegem Yayincilik, Ankara.

Brewer, B.W., VanRaalte, J.L. \& Linder, D.E. (1993): Athletic identity: hercules' muscles or achilles heel? Int. J. Sport Psychol., (24):237-254.

Brewer, B.W., Boin, P., Petitpas, A., Van Raalte, J. \& Mahar, M. (1993a): Dimensions of athletic identity. Paper Presented At The Annual Meeting of American Psychological Association, Toronto, Ontario, Canada.

Cornelius, A. (1995): The relationship between athletic identity, peer and faculty socialization, and college student development. J. Coll. Stu. Develop., (36):560-573.

Çelik, A. \& Sahin, M. (2013): Spor ve çocuk gelisimi. Int. J. Social Sci., 6(1):467-478.

Çetinkaya, T. (2010): Sporcu ögrenci kimligi olusumunda etkili olan faktörler. Yayimlanmamis Yüksek Lisans Tezi, Gazi Üniversitesi Saglik Bilimleri Enstitüsü, Ankara.

Çetinkaya, T. (2015): Takim sporlarinda sporcu kimligi ve sürekli sportif kendine güven iliskisi. Yayimlanmamis Doktora Tezi, Gazi Üniversitesi, Ankara.

Elasky, M.E. (2006): Athletic identity and its relation to life satisfaction: comparing division-i and division-iii athletes and gender. Ph.D. diss., Miami University, Miami.

Görgülü, R., Adilogullari, G.E., Tosun, Ö.M. \& Adilogullari, I. (2018): Prososyal ve antisosyal davranis ile sporcu kimliginin bazi degiskenlere göre incelenmesi. Spor ve Performans Arastirmalari Dergisi, 9(3):147-161.

Jana, N. (2015): Developing the entrepreneurial competencies of sport management students. Procedia, (174):3916-24.

Murphy, J.G., Petitpas, A. \& Brewer, B.W. (1996): Identity foreclosure, athletic identity, and career maturity in intercollegiate athletes. Sport Psychol., 10:239-246.

Oregon, E.M. (2010): An examination of athletic identity and identity foreclosure among male collegiate studentathlete. Ph.D. diss., University of N. Carolina, Harris Hall.

Özkara, A.B. \& Özbay, S. (2019): Examination of the psychological resilience of students athletes at high school level. Milli Egitim Dergisi, 48(221):207-214.

Öztürk, P. \& Koca, C. (2013): Sporcu kimligi ölçeginin türkçe formunun psikometrik özelliklerinin incelenmesi. Spor Bilimleri Dergisi, 24(1):1-10.

Proios, M. (2013): Athletic identity and social goal orientations as predictors of moral orientation. Ethic. Behav., 23(5):410-424.

Tabachnick, B. \& Fidell, L. (2013): Using multivariate statistics (6th International edition cover edn). Pub. by: New Jersey: Sage Publications, Thousand Oaks.

Wiechman, S.A. \& Williams, J. (1997): Factors affecting athletic identity and expectations in the high school student athlete. L. Sport Behav., (20):199-211.

Yilmaz, E. \& Sünbül, A.M. (2009): Üniversiteögrencilerineyönelik girisimcilik ölçeginin gelistirilmesi. Selçuk Üniversitesi Sosyal Bilimler Enstitüsü Dergisi, 21:195-203. 